Article

\title{
Donor-acceptor carbon nitride with electron-withdrawing chlorine group to promote exciton dissociation
}

\author{
Jing-Wen Zhang a, Lun Pan a,b, Xiangwen Zhang a,b, Chengxiang Shi a,\#, Ji-Jun Zou a,b,* \\ a Key Laboratory for Green Chemical Technology of the Ministry of Education, School of Chemical Engineering and Technology, Tianjin University, \\ Tianjin 300072, China \\ b Collaborative Innovative Center of Chemical Science and Engineering (Tianjin), Tianjin 300072, China
}

\section{A R T I C L E I N F O}

\section{Article history:}

Received 18 September 2020

Accepted 3 November 2020

Available online 5 March 2021

\section{Keywords:}

Carbon nitride

Donor-acceptor

Internal electric field

Exciton

Hydrogen production

\begin{abstract}
A B S T R A C T
Carbon nitride $\left(\mathrm{C}_{3} \mathrm{~N}_{4}\right)$ is promising for photocatalytic hydrogen production, but photogenerated electrons and holes in $\mathrm{C}_{3} \mathrm{~N}_{4}$ usually tend to exist as excitons due to intrinsic Coulomb interactions making its photocatalytic activity unsatisfactory. Herein, a well-designed intramolecular $\mathrm{C}_{3} \mathrm{~N}_{4}$-based donor-acceptor (D-A) photocatalytic system was constructed to promote exciton dissociation. Due to its good chemical compatibility with melamine and appropriate sublimation property, 2-amino-4,6-dichloropyrimidine unit was chosen as the monomer to react with melamine to construct intramolecular D-A system $\left(\mathrm{CNCl}_{x}\right)$. The hydrogen evolution rate of $\mathrm{CNCl}_{0.15}$ is 15.3 times higher than that of bulk $\mathrm{C}_{3} \mathrm{~N}_{4}$ under visible light irradiation, with apparent quantum efficiency of $13.6 \%$ at $420 \mathrm{~nm}$. The enhanced activity is attributed to introduced electron-withdrawing $-\mathrm{Cl}$ group as terminal group in the resulted $\mathrm{CNCl}_{x}$ samples, which can build internal electric field to promote the exciton dissociation into free electron and hole. In addition, lower work function value of $\mathrm{CNCl}_{x}$ samples indicates that internal electric field can help free electrons and holes transfer to the surface of $\mathrm{CNCl}_{x}$ samples for photocatalytic reaction.
\end{abstract}

(C) 2021, Dalian Institute of Chemical Physics, Chinese Academy of Sciences. Published by Elsevier B.V. All rights reserved.

\section{Introduction}

Water splitting under visible light using polymer photocatalysts is a promising technology for sustainable hydrogen production [1,2]. Polymeric carbon nitride $\left(\mathrm{C}_{3} \mathrm{~N}_{4}\right)$ has emerged as an attractive photocatalyst for water splitting and pollutant degradation because of the ability to absorb visible light efficiently, chemical stability and non-toxicity [3]. Unfortunately, photogenerated electrons and holes in $\mathrm{C}_{3} \mathrm{~N}_{4}$ usually tend to exist as excitons due to intrinsic Coulomb interactions making its photocatalytic activity unsatisfactory [4]. So, there have been a lot of efforts promoting exciton dissociation into free electrons and holes to enhance the carriers separation efficiency of $\mathrm{C}_{3} \mathrm{~N}_{4}$ [5]. Donor-Acceptor (D-A) system is an effective way to promote exciton dissociation because it can induce internal electric field which promotes the exciton to dissociate into free electrons and holes. And then free electrons and holes transfer to the surface of catalyst with the help of internal electric field [6-8].

In the past few years, various intramolecular copolymers have been constructed to form D-A systems based on $\mathrm{C}_{3} \mathrm{~N}_{4}$ [9-12]. In 2009, Wang et al. [13] synthesized $\mathrm{C}_{3} \mathrm{~N}_{4}$ with D-A structures by simple copolymerization with organic monomer (barbituric acid) for the first time. The resulted sample showed

\footnotetext{
* Corresponding author. Tel/Fax: +86-22-27892340; E-mail: jj_zou@tju.edu.cn \# Corresponding author. Tel/Fax: +86-22-27892340; E-mail: cxshi@tju.edu.cn

This work was supported by the National Natural Science Foundation of China $(21676193,21978200,51661145026)$.

DOI: 10.1016/S1872-2067(20)63733-0 | http://www.sciencedirect.com/journal/chinese-journal-of-catalysis | Chin. J. Catal., Vol. 42, No. 7, July 2021
} 
extended absorption region and enhanced hydrogen evolution rate. Inspired by this work, variety of organic monomers were exploited, like benzene [14,15], naphthalene [16], and so on [17]. The introduction of these monomers always resulted facilitated charge separation. Except for the organic monomers, -Se [18], $-\mathrm{C} \equiv \mathrm{N}[19,20]$, oxygen group (C-O-C and $\mathrm{C}=0$ ) [21] were also incorporated to $\mathrm{C}_{3} \mathrm{~N}_{4}$ for constructing D-A copolymers.

Although a lot of efforts have been made to construct intramolecular copolymers with D-A structure, and these $\mathrm{C}_{3} \mathrm{~N}_{4}$-based copolymers showed enhanced performance for photocatalysis, there are still several points that need paying more attention to: (1) the chemical compatibility of the monomer with the precursor molecule of $\mathrm{C}_{3} \mathrm{~N}_{4}$; (2) the sublimation property and temperature of the introduced monomer which are very important for the copolymerization process; (3) the final position of the monomer in the copolymer. Herein, this work takes these three points into account and chooses 2-amino-4,6-dichloropyrimidine $\left(\mathrm{C}_{4} \mathrm{H}_{3} \mathrm{Cl}_{2} \mathrm{~N}_{3}\right)$ as the monomer. $\mathrm{C}_{4} \mathrm{H}_{3} \mathrm{Cl}_{2} \mathrm{~N}_{3}$ has good chemical compatibility with melamine $\left(\mathrm{C}_{3} \mathrm{~N}_{3}\left(\mathrm{NH}_{2}\right)_{3}\right.$, the precursor of $\left.\mathrm{C}_{3} \mathrm{~N}_{4}\right)$, because their molecular structures are similar. During the copolymerization process, $\mathrm{C}_{4} \mathrm{H}_{3} \mathrm{Cl}_{2} \mathrm{~N}_{3}$ sublimates at $219-22{ }^{\circ} \mathrm{C}$ and then melamine sublimates at $300{ }^{\circ} \mathrm{C}$, resulting the sufficient gas-phase mixture for copolymerization. When the temperature continues to rise, the copolymerization process will take place. If the $\mathrm{C}_{4} \mathrm{H}_{3} \mathrm{Cl}_{2} \mathrm{~N}_{3}$ molecules react with $\mathrm{C}_{3} \mathrm{~N}_{3}\left(\mathrm{NH}_{2}\right)_{3}$, the polymerization will end at this direction, thus the electron-withdrawing - $\mathrm{Cl}$ groups will all locate at the terminal of the copolymers which will be helpful for the construction of D-A system.

\section{Experimental}

\subsection{Materials}

Melamine $\quad\left(\mathrm{C}_{3} \mathrm{~N}_{6} \mathrm{H}_{6}\right), \quad$ 2-amino-4,6-dichloropyrimidine $\left(\mathrm{C}_{4} \mathrm{H}_{3} \mathrm{Cl}_{2} \mathrm{~N}_{3}\right)$, and triethanolamine (TEOA) were purchased from Aladdin Industry Corporation. Chloroplatinic acid hexahydrate $\left(\mathrm{H}_{2} \mathrm{PtCl}_{6} \cdot 6 \mathrm{H}_{2} \mathrm{O}\right)$, methyl orange (MO) and rhodamine $\mathrm{B}$ (RhB) were obtained from Guangfu Institute, China. Phenol was purchased from J\&K Chemical. All the chemicals were reagent grade and used without further purification. Milli-Q ultra-pure water was obtained from HYP-QX machine.

\subsection{Fabrication of D-A copolymers}

$2.5224 \mathrm{~g}$ of melamine $(0.02 \mathrm{~mol})$ was mixed thoroughly with a certain amount of $(0.001,0.002,0.003$ and $0.004 \mathrm{~mol})$ 2-amino-4,6-dichloropyrimidine $\left(\mathrm{C}_{4} \mathrm{H}_{3} \mathrm{Cl}_{2} \mathrm{~N}_{3}\right)$. The mixture was then calcined in air at $550{ }^{\circ} \mathrm{C}$ for $4 \mathrm{~h}$, while the heating rate is $2.3^{\circ} \mathrm{C} / \mathrm{min}$. The obtained products are denoted as $\mathrm{CNCl}_{x}$, where the $x$ values $(0.05,0.1,0.15$, and 0.2$)$ represent the molar ratios of $\mathrm{C}_{4} \mathrm{H}_{3} \mathrm{Cl}_{2} \mathrm{~N}_{3}$ to melamine. For comparison, bulk $\mathrm{C}_{3} \mathrm{~N}_{4}$ (donated as BCN) was also fabricated by calcining melamine at $550{ }^{\circ} \mathrm{C}$ for $4 \mathrm{~h}$ [21].

\subsection{Characterizations}

X-Ray diffraction (XRD) characterizations were conducted on a X'Pert Pro X-ray diffractometer equipped with $\mathrm{Cu} K_{\alpha}$ radiation at $40 \mathrm{kV}$ and $40 \mathrm{~mA}$. FT-IR spectra were recorded on a Bruker Vertex70 spectrometer. The morphologies of synthesized samples were obtained with Hitachi S-4800 FE-SEM (scanning electron microscope) and JEM-2100F TEM (transmission electron microscope). The chemical states were conducted on a Thermo Scientific K-Alpha X-ray photoelectron spectroscope (XPS). Time-resolved photoluminescence spectra decays were recorded on an Edinburgh Instrument (FLS 980, $\lambda$ $=375 \mathrm{~nm}$ ). Steady-state photoluminescence (PL) spectra were taken on a HITACHI F-4600 instrument $(\lambda=375 \mathrm{~nm}) . \mathrm{N}_{2}$ adsorption and desorption isotherms were conducted on a Quantachrome Instruments Quadrasorb EVO at $77 \mathrm{~K}$. UV-vis diffuse reflectance spectra (DRS) were obtained on a SHIMADZU UV-2600 spectrometer using $\mathrm{BaSO}_{4}$ as reference. Nuclear Magnetic Resonance (NMR) was performed with Bruker AVANCE III $600 \mathrm{MHz}$ solid-state nuclear magnetic spectrometer. Electron paramagnetic resonance (EPR) measurement was performed with a JES FA200 spectrometer. Ultroviolet photoelectron spectrometer (UPS) measurements were performed with an American ThermoFischer, ESCALAB 250Xi instrument.

\subsection{Photocatalytic hydrogen evolution and organics degradation performance}

Photocatalytic hydrogen evolution performance was tested in a closed Pyrex top-irradiation vessel (280 mL). Firstly, $50 \mathrm{mg}$ photocatalyst was dispersed in $100 \mathrm{~mL}$ triethanolamine solution (10 vol\%) under ultrasonic treatment for $30 \mathrm{~min}$. After that, $405 \mu \mathrm{L} \mathrm{H}_{2} \mathrm{PtCl}_{6}$ aqueous solution was added. Then, $3 \mathrm{wt} \%$ $\mathrm{Pt}$ as co-catalyst was introduced by in-situ photodeposition method. The reaction solution was purged with Ar for $30 \mathrm{~min}$ to completely remove air until the pressure up to $101 \mathrm{kPa}$. The reaction was conducted at $0.5{ }^{\circ} \mathrm{C}$ under a $300 \mathrm{~W}$ Xeon-lamp (PLS-SXE300UV, Beijing Trusttech. Co. Ltd.) equipped with a $420 \mathrm{~nm}$-cut-off filter. The evolved gas was analyzed on gas chromatography (Bruker 450-GC) equipped with a thermal conductive detector (TCD) and a $5 \AA$ molecular sieve column, using Ar gas as the carrier gas.

The apparent quantum yield (AQY) was calculated as AQY = $\mathrm{Ne} / \mathrm{Np} \times 100 \%$, where $\mathrm{Ne}$ is the amount of reaction electrons, $N \mathrm{p}$ is the amount of incident photons. The irradiation area was $20 \mathrm{~cm}^{2}$. The intensity of incident light was measured using a UV-A radiometer (Photoelectric Instrument Factory, Beijing Normal University, model UV-A). For $420 \mathrm{~nm}$ monochromatic light, the intensity was $7.51 \mathrm{~mW} / \mathrm{cm}^{2}$. Ne is calculated based on the average amount of hydrogen produced per hour.

Photodegradation of organics (RhB, phenol, and MO) was conducted in an opening quartz chamber $(150 \mathrm{~mL})$ under the vertical irradiation of a $300 \mathrm{~W}$ high-pressure Xenon lamp. The detailed reaction conditions are listed as follows: the reaction temperature $25 \pm 0.2^{\circ} \mathrm{C}$, the weight content of photocatalyst $0.2 \mathrm{~g} / \mathrm{L}, C_{0}(\mathrm{RhB})=20 \mu \mathrm{mol} \cdot \mathrm{L}^{-1}, C_{0}(\mathrm{MO})=120 \mu \mathrm{mol} \cdot \mathrm{L}^{-1}$, $C_{0}($ Phenol $)=400 \mu \mathrm{mol} \cdot \mathrm{L}^{-1}$. Before the photodegradation reaction, the suspension composed of organic solution and photo- 
catalyst was stirred for 20 min in black to achieve adsorption equilibrium. For comparison, the self-degradation of RhB, phenol, and MO was conducted without any catalysts under light irradiation. The concentrations of organics were analyzed by UV-vis spectrometer.

\subsection{Photoelectrochemical measurements}

The photoelectrochemical measurements were performed on a CHI 660e electrochemical system. Firstly, $20 \mathrm{mg}$ sample was dispersed in $2 \mathrm{~mL}$ ethanol and then $20 \mu \mathrm{L}$ Nafion was added. Secondly, the dispersion was sonicated for 2 hours and dip-coated on an F-doped tin oxide (FTO) glass electrode $(2 \times 2$ $\mathrm{cm}^{2}$ ), which was ultrasonically in acetone solution to remove surface impurities before using. Thirdly, the FTO glass electrode was heated to $150{ }^{\circ} \mathrm{C}$ and maintained at $150{ }^{\circ} \mathrm{C}$ for $12 \mathrm{~h}$. A standard three-electrode cell was composed of the prepared FTO glass electrode coated with sample (working electrode), a platinum wire counter electrode, an $\mathrm{Ag} / \mathrm{AgCl}$ reference electrode. Electrolyte is $0.2 \mathrm{M} \mathrm{Na}_{2} \mathrm{SO}_{4}$ solution. The electrochemical impedance spectroscopy (EIS) were tested with a sinusoidal ac perturbation of $0.1 \mathrm{~V}$ applied over the frequency range of $0.01-10^{5} \mathrm{~Hz}$.

\section{Results and discussion}

\subsection{Structure and morphology}

The crystal structures of prepared $\mathrm{C}_{3} \mathrm{~N}_{4}$ materials were firstly investigated by XRD. As shown in Fig. 1(a), BCN and $\mathrm{CNCl}_{x}$ show two typical diffraction peaks at $13.2^{\circ}$ and $27.4^{\circ}$. The peak at $13.2^{\circ}$ is attributed to the in-plane intervals of periodic tri-s-triazine units (100) plane. And the peak at $27.4^{\circ}$ arises from the interplanar stacking of aromatic systems (002) plane of graphitic $\mathrm{C}_{3} \mathrm{~N}_{4}$ (JCPDS No. 87-1526), while the peak of (002) plane tends to be broadened and weakened from BCN to $\mathrm{CNCl}_{0.2}$, indicating the reduced size and/or the decreased thickness of $\mathrm{C}_{3} \mathrm{~N}_{4}$ nanosheets. The SEM images and TEM images of synthesized $\mathrm{C}_{3} \mathrm{~N}_{4}$ materials were displayed in Figs. 1(b-f) and Figs. 2(a-e). As shown in Fig. 1(b), the nanosheets are
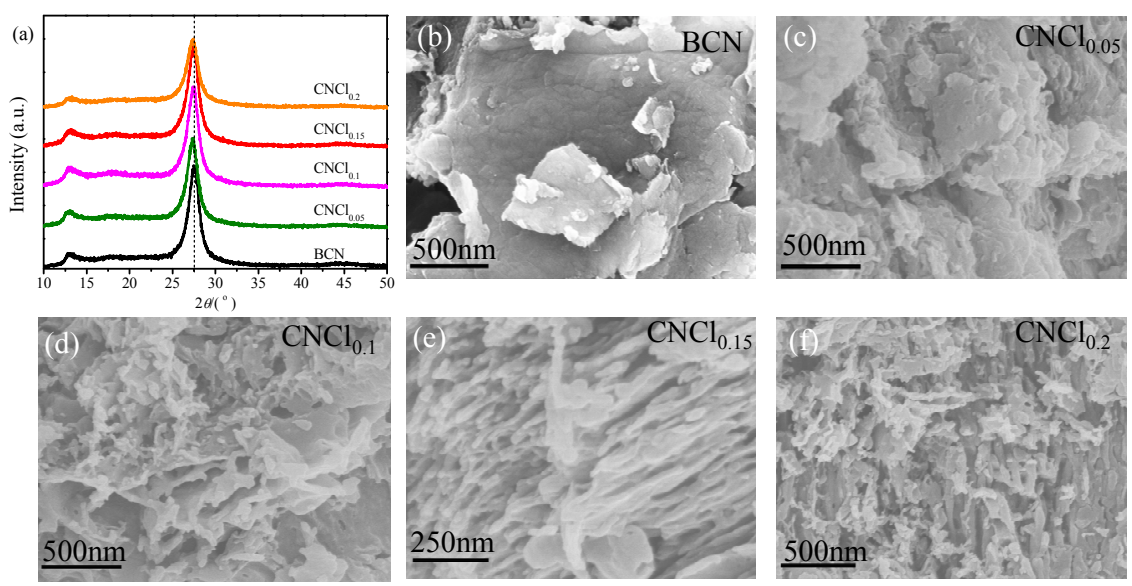

Fig. 1. (a) The XRD pattern $\mathrm{BCN}$ and $\mathrm{CNCl}_{x} ; \mathrm{SEM}$ images of $\mathrm{BCN}(\mathrm{b}), \mathrm{CNCl}_{0.05}(\mathrm{c}), \mathrm{CNCl}_{0.1}(\mathrm{~d}), \mathrm{CNCl}_{0.15}(\mathrm{e})$, and $\mathrm{CNCl}_{0.2}(\mathrm{f})$.
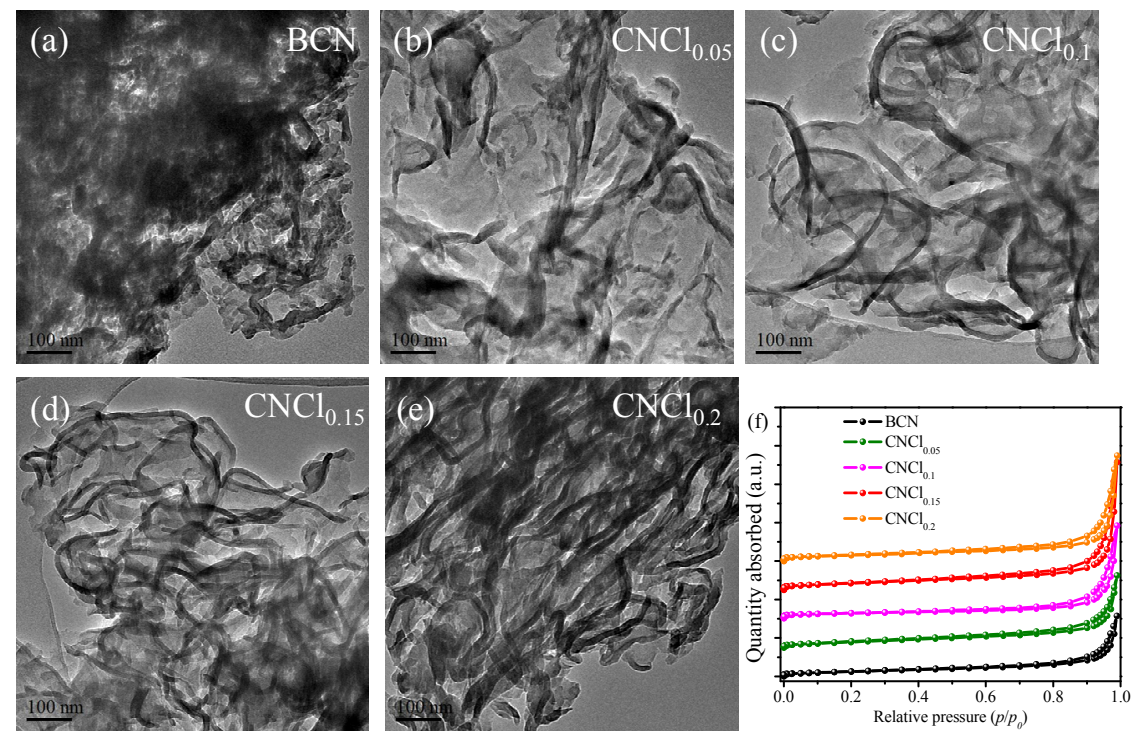

Fig. 2. The TEM images of $\mathrm{BCN}(\mathrm{a}), \mathrm{CNCl}_{0.05}$ (b), $\mathrm{CNCl}_{0.1}$ (c), $\mathrm{CNCl}_{0.15}$ (d), $\mathrm{CNCl}_{0.2}$ (e); (f) $\mathrm{BET}$ surface area of $\mathrm{bulk}_{3} \mathrm{~N}_{4}$ and $\mathrm{CNCl}_{x}$. 
densely packed in form of bulk particles without obvious porosity in $\mathrm{BCN}$. While $\mathrm{CNCl}_{x}$ samples show less compact and porous structures with variable ordering (Figs. 1(c-f)), among which $\mathrm{CNCl}_{0.15}$ shows the most ordered structure. Moreover, the nanosheets become smaller and thinner with increasing the amount of $\mathrm{C}_{4} \mathrm{H}_{3} \mathrm{Cl}_{2} \mathrm{~N}_{3}$, which can also be confirmed by the TEM images (Figs. 2(b-e)) and is consistent with the result of XRD. $\mathrm{N}_{2}$ adsorption-desorption measurements were performed to further investigate the porous structures of copolymers (Figs. 2(f) and S1). The surface area increases from bulk $\mathrm{C}_{3} \mathrm{~N}_{4}\left(16 \mathrm{~m}^{2}\right.$ $\left.\mathrm{g}^{-1}\right)$ to $\mathrm{CNCl}_{0.15}\left(24 \mathrm{~m}^{2} \mathrm{~g}^{-1}\right)$. But it decreases for $\mathrm{CNCl}_{0.2}\left(21 \mathrm{~m}^{2}\right.$ $\mathrm{g}^{-1}$ ) because the sheets tend to aggregate, which can be proved by the TEM image of $\mathrm{CNCl}_{0.2}$ (Fig. 2(e)).

The FT-IR spectras of $\mathrm{BCN}$ and $\mathrm{CNCl}_{x}$ samples demonstrate typical aromatic $\mathrm{C}-\mathrm{N}$ heterocycle stretches at $1200-1700 \mathrm{~cm}^{-1}$ and the triazine units breathing mode at $806 \mathrm{~cm}^{-1}$ (Fig. 3(a)). The broad peak at $2800-3400 \mathrm{~cm}^{-1}$ arises from the $\mathrm{N}-\mathrm{H}$ of the residual uncondensed amino groups and $\mathrm{O}-\mathrm{H}$ bands of the absorbed $\mathrm{H}_{2} \mathrm{O}$ molecules [22]. The vibrations of $\mathrm{C}-\mathrm{Cl}$ group are hardly observed in $\mathrm{CNCl}_{x}$, presumably because its content is low and its vibration is overlapped with those of $\mathrm{C}-\mathrm{N}$ heterocycle [23]. Even if the molar ratio of $\mathrm{C}_{4} \mathrm{H}_{3} \mathrm{Cl}_{2} \mathrm{~N}_{3}$ to melamine is raised up to 0.5 , the vibrations of $\mathrm{C}-\mathrm{Cl}$ groups are still not visible (Fig. S2). As shown in Fig. 3(b), the ${ }^{13} \mathrm{C}$ NMR spectrum of $\mathrm{BCN}$ and $\mathrm{CNCl}_{0.15}$ both display two typical signals at 164.92 and 157.05 ppm, which correspond to $\mathrm{C}$ atoms bonded to external groups ( $\mathrm{C}-\mathrm{NH}$ ) and $\mathrm{C}$ atoms linked trigonally to three $\mathrm{N}$ atoms

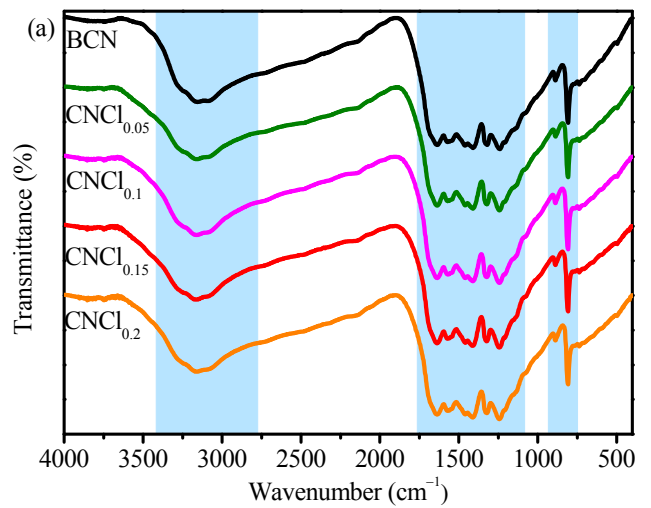

(C-N3), respectively [24,25], indicating that $-\mathrm{Cl}$ groups don't influence the chemical shift of intrinsic lattice C. Combined with the results of FT-IR, we can conclude that the -Cl groups don't disturb the intrinsic structure of $\mathrm{C}_{3} \mathrm{~N}_{4}$, confirming that $-\mathrm{Cl}$ groups don't substitute the lattice $\mathrm{C}$ or $\mathrm{N}$ atom.

XPS spectra were studied to investigate the chemical states. The XPS spectra of C $1 s$ and N $1 s$ orbitals are displayed in Fig. 4. As shown in Fig. 4(a), the peak at $284.8 \mathrm{eV}$ corresponds to carbon impurities from carbon contamination [26]. The peaks at $288.1 \mathrm{eV}$ corresponds to $s p^{2}$-hybridized $\mathrm{C}$ in the $\mathrm{N}$-containing aromatic ring, which is the major aromatic carbon species of $\mathrm{C}_{3} \mathrm{~N}_{4}$. The peak attributed to the $\mathrm{C}-\mathrm{NH}_{x}$ species is at $285.7 \mathrm{eV}$ of bulk $\mathrm{C}_{3} \mathrm{~N}_{4}$, while the binding energy shifts towards the high energy side after introducing the $-\mathrm{Cl}$ group due to the decrease of electron density of $\mathrm{C}-\mathrm{NH}_{x}[27,28]$. This result proves that different terminal groups (electron-donating group $\mathrm{C}-\mathrm{NH}_{x}$ and electron-withdrawing group $-\mathrm{Cl}$ ) change the electron distribution of the heptazine heterocyclic structure, which can build internal electric field in the $\mathrm{CNCl}_{x}$ samples. The internal electric field helps the exciton dissociation into free electrons and holes. The high-resolution N 1s XPS spectrum (Fig. 4(b)) shows that the main species is at $398.6 \mathrm{eV}$ attributed to $s p^{2}$-hybridized nitrogen $(\mathrm{C}-\mathrm{N}=\mathrm{C})$ center involved in triazine rings. And the weak peak at 400.4 and $401.2 \mathrm{eV}$ is attributed to the tertiary nitrogen $\mathrm{N}-(\mathrm{C})_{3}$ groups and amino groups $(\mathrm{C}-\mathrm{N}-\mathrm{H})$, respectively [29]. As for the content of $\mathrm{Cl}$, XPS result shows that the overall concentration in $\mathrm{CNCl}_{0.15}$ is $0.2 \mathrm{~mol} \%$, but the result is

Fig. 3. (a) The FT-IR spectra and NMR spectra of bulk $\mathrm{C}_{3} \mathrm{~N}_{4}$ and $\mathrm{CNCl}_{x}$; (b) NMR spectra of bulk $\mathrm{C}_{3} \mathrm{~N}_{4}$ and $\mathrm{CNCl}_{0.15}$.
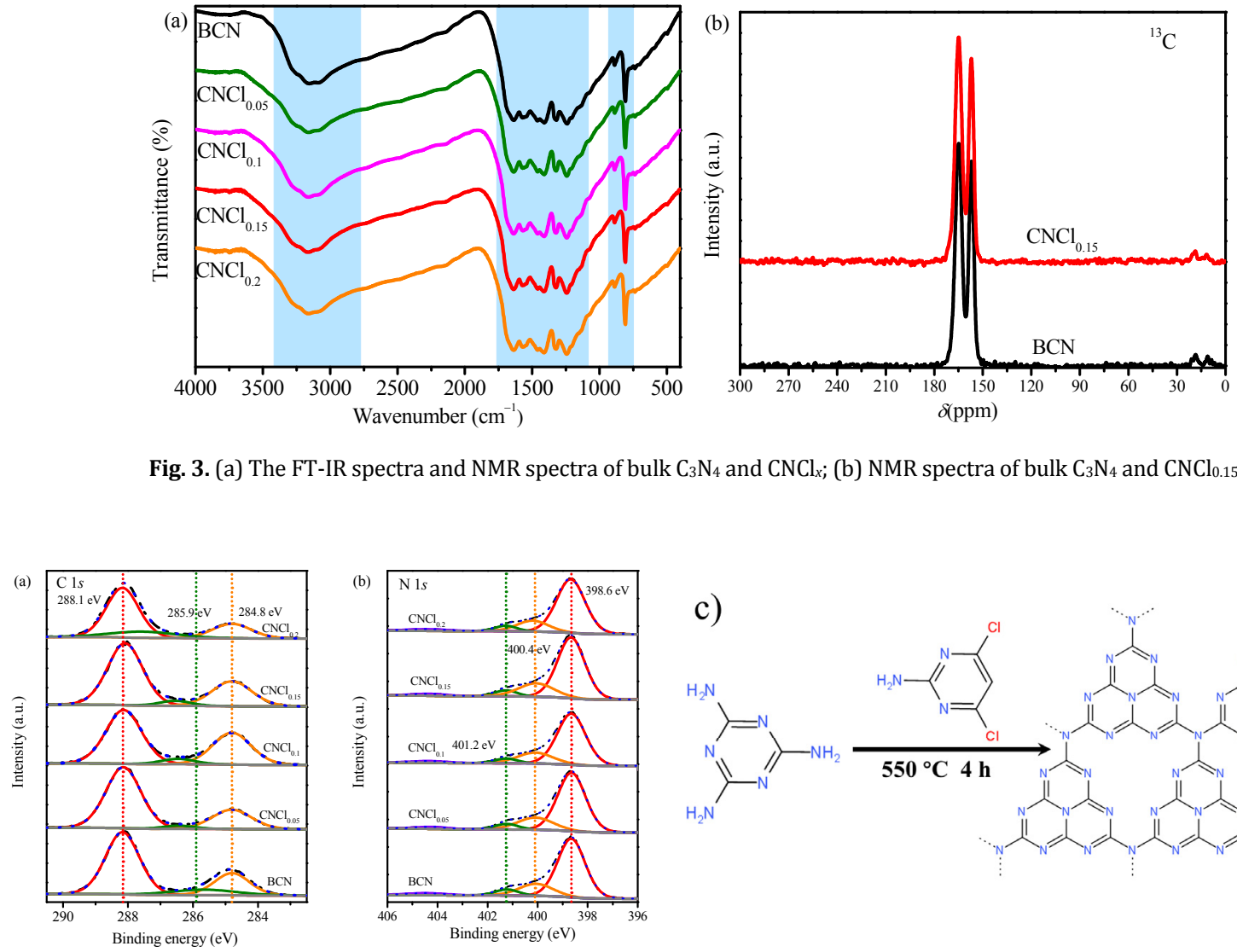

Fig. 4. (a,b) High-resolution XPS spectra of the $\mathrm{BCN}$ and $\mathrm{CNCl}_{x}$; (c) The structure of $\mathrm{CNCl}_{x}$ copolymer. 

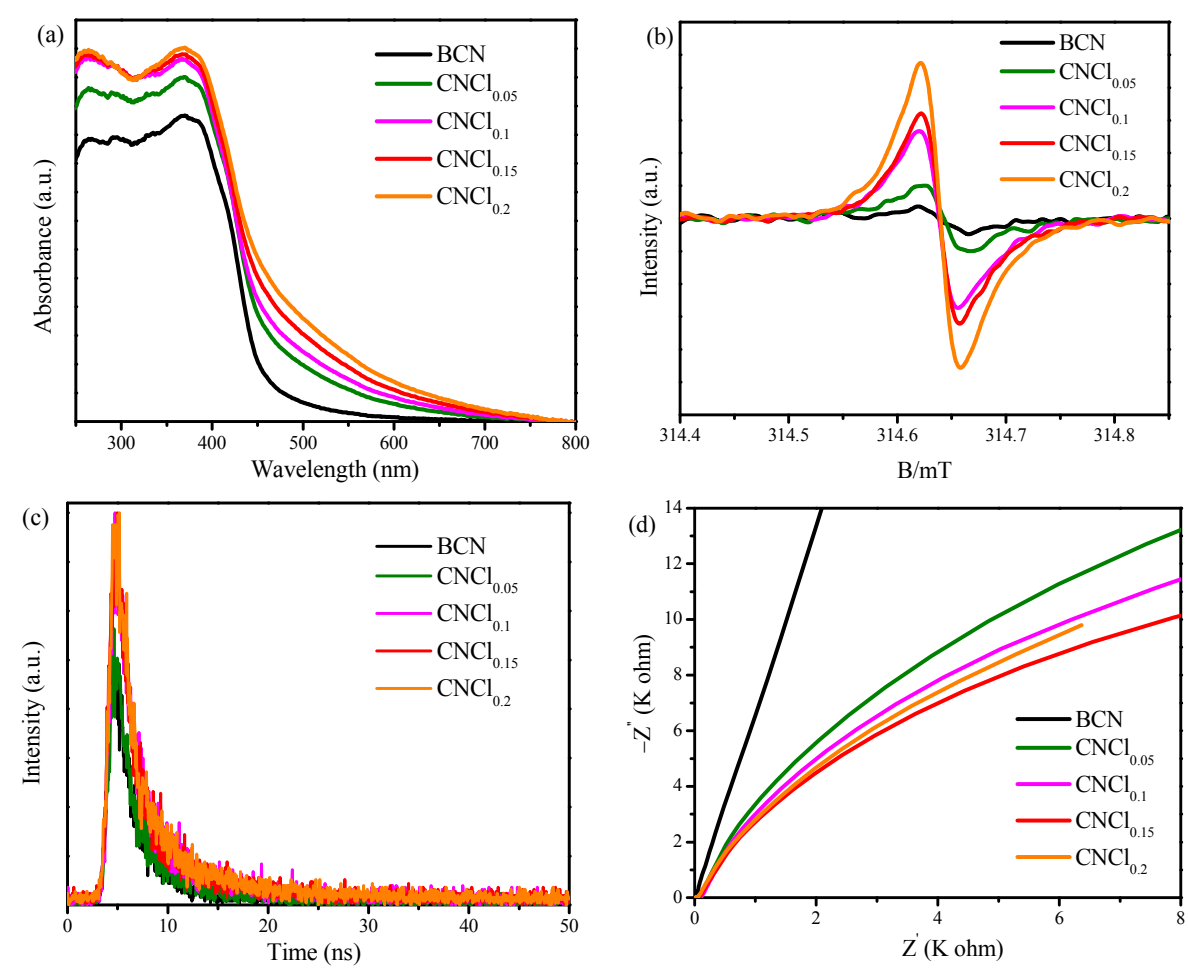

Fig. 5. (a) UV-vis absorption spectra; (b) Room-temperature EPR spectrum; (c) Time-resolution fluorescence spectra; (d) Electrochemical impedance spectroscopy of $\mathrm{BCN}$ and $\mathrm{CNCl}_{x}$.

not convincing when the atomic percentage content is less than $1 \%$. Hence, we investigated the content of $\mathrm{Cl}$ in the prepared $\mathrm{CNCl}_{0.5}$ sample, in which the atomic percentage content of $\mathrm{Cl}$ is $1.5 \%$ (Fig. S3 and Table S1), indicating that $-\mathrm{Cl}$ group can be incorporated into $\mathrm{C}_{3} \mathrm{~N}_{4}$ through the co-calcination of $\mathrm{C}_{4} \mathrm{H}_{3} \mathrm{Cl}_{2} \mathrm{~N}_{3}$ and melamine [30].

Both C $1 s$ and $\mathrm{N} 1 s$ spectra results are consistent with the result of FT-IR spectra that basic heptazine heterocyclic structure doesn't change after introducing $-\mathrm{Cl}$ group into $\mathrm{C}_{3} \mathrm{~N}_{4}$, except the electron density of $\mathrm{C}-\mathrm{NH}_{x}$ species. From the above results, the structure of $\mathrm{CNCl}_{x}$ is proposed in Fig. 4(c). As indicated, the incorporated $-\mathrm{Cl}$ groups are located at the terminals of the copolymer.

Fig. 5(a) shows the UV-vis absorption spectra. With increasing the amount of - $\mathrm{Cl}$ groups, the absorption band edge of the $\mathrm{CNC1}_{x}$ sample has a red shift and the light absorption value gradually increases. This is because when the electron donating group and the electron withdrawing group exist at the same time, the intramolecular charge-transfer absorption can occur [31]. This result further confirms the existence of the internal electric field [32]. Based on the UV-vis absorption spectra, the optical band gaps of as-prepared samples were evaluated by a classical Tauc approach [33]. Fig. S4(b) shows the band gap of BCN is $2.7 \mathrm{eV}$. As shown in Figs. S4(c-f), the band gap decreases from 2.67 to $2.61 \mathrm{eV}$ with increasing the terminal $-\mathrm{Cl}$ group from $\mathrm{CNCl}_{0.05}$ to $\mathrm{CNCl}_{0.2}$, indicating that the introduction of terminal -Cl group can regulate the electronic structure of $\mathrm{C}_{3} \mathrm{~N}_{4}$.

To further confirm the electronic structure of $\mathrm{CNCl}_{x}$, EPR was conducted. As shown in Fig. 5(b), all samples exhibit one single Lorentzian line with a $g$ value of 2.0034 , attributing to the unpaired electrons in the $\mathrm{CB}$ of $\mathrm{C}_{3} \mathrm{~N}_{4}$ [34]. Compared with the pristine $\mathrm{C}_{3} \mathrm{~N}_{4}$, the EPR signals are much enhanced for $\mathrm{CNCl}_{x}$ samples and the highest for $\mathrm{CNCl}_{0.2}$ samples. Note that the higher EPR intensity is an indication of the higher concentration of unpaired electrons $[34,35]$. It could be then deduced that the introduction of $-\mathrm{Cl}$ offers internal electric field, which has a strong ability to delocalize electrons and thus benefits the photoinduced generation of charge carriers for photocatalytic reaction. Time-resolved photoluminescence (PL) spectra was measured to investigate the lifetime of charge carriers. As revealed in Fig. 5(c), the lifetimes $(\tau)$ are 1.89, 2.23, 2.46, 3.88, 4.06 ns for $\mathrm{BCN}$ and $\mathrm{CNCl}_{x}$ samples, which shows the same trend in the steady-state PL spectra (Fig. S5), indicating the enhanced exciton dissociation efficiency with the increased amount of $-\mathrm{Cl}$ group. This result suggests that the intensity of internal electric field enhances with the amount of $-\mathrm{Cl}$ group [36].

\subsection{Photocatalytic performance}

The photocatalytic performances of the composites were evaluated by degrading organic pollutants and hydrogen evolution reaction (HER) under visible light irradiation $(\lambda>420 \mathrm{~nm})$. In Fig. $6(\mathrm{a})$, it is obvious that $\mathrm{CNCl}_{x}$ shows an enhanced rate by a factor of $6-15$ over $168.7 \mu \mathrm{mol} \cdot \mathrm{h}^{-1} \cdot \mathrm{g}^{-1}$ of bulk $\mathrm{C}_{3} \mathrm{~N}_{4}$. Especially, the $\mathrm{H}_{2}$ evolution rate of $\mathrm{CNCl}_{0.15}$ reaches $2585.3 \mu \mathrm{mol} \cdot \mathrm{h}^{-1} \cdot \mathrm{g}^{-1}$, which is about 15.3-fold of bulk $\mathrm{C}_{3} \mathrm{~N}_{4}$. to In order to distinguish the contribution of surface area and - $\mathrm{Cl}$ terminal groups to the overall activity, the HER rate is normalized by the surface area. As shown in Fig. 6(a), $\mathrm{CNCl}_{x}$ samples show higher normalized 

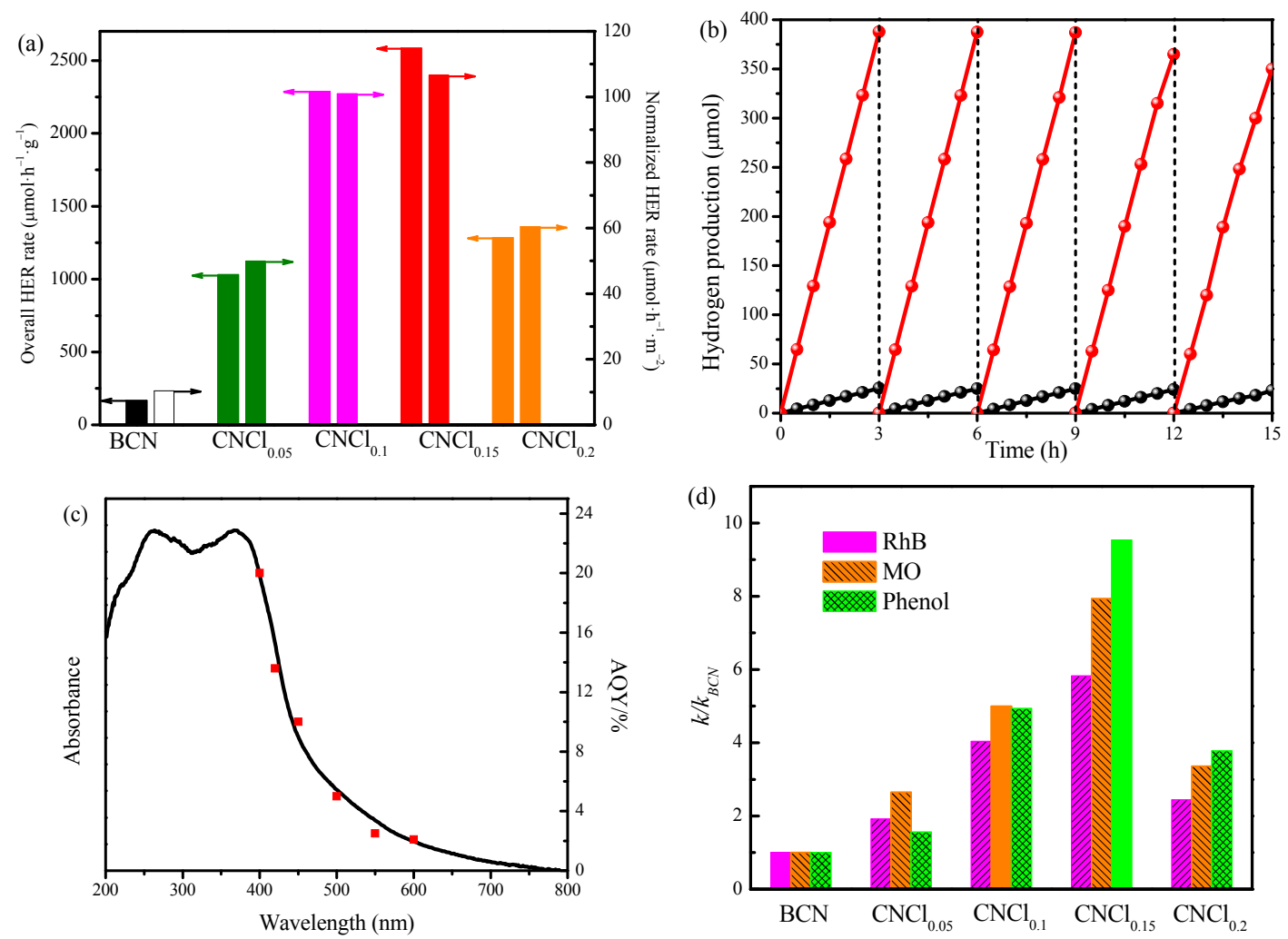

Fig. 6. (a) Photocatalytic hydrogen evolution rates of $\mathrm{CN}$ and $\mathrm{CNCl}_{x}$ samples under visible light irradiation; cycling stability test (b) and wavelength-dependent apparent quantum yield (c) of $\mathrm{CNCl}_{0.15}$; (d) Degradation of organic pollutants of $\mathrm{CN}$ and $\mathrm{CNCl}_{x}$ samples under visible light irradiation.

activity than bulk $\mathrm{C}_{3} \mathrm{~N}_{4}$, indicating that surface area is not the inherent reason for the improvement of the performance. The proposed schematic illustration of charge transfer in $\mathrm{CNCl}_{x}$ under visible-light irradiation is shown in Fig. 7. And the improvement of activity is mainly due to the enhancement of photoabsorption and exciton dissociation efficiency with the increase of terminal $-\mathrm{Cl}$ groups (Figs. $5(\mathrm{a}-\mathrm{c})$ ). However, $-\mathrm{Cl}$ groups can also act as the trap sites for electrons, thus decreasing the efficiency of charge transfer. This is testified by the Nyquist plots of EIS, transient photocurrent response and UPS results. The smallest arc radius and highest transient photocurrent response of $\mathrm{CNCl}_{0.15}$ among all the samples suggested the minimum resistance and highest carrier transfer efficiency (Figs. 5(d) and S6). The work function values of $\mathrm{BCN}$ and $\mathrm{CNCl}_{x}$ samples (Fig. S7) investigated by UPS measurement. Referring to the calculation method in previous report [37], the work function values (difference between the Fermi and vacuum level) for $\mathrm{BCN}, \mathrm{CNCl}_{0.05}, \mathrm{CNCl}_{0.1}, \mathrm{CNCl}_{0.15}$ and $\mathrm{CNCl}_{0.2}$ are calculated to be $4.4,4.39,4.11,3.75$ and $4.28 \mathrm{eV}$, respectively. Because work function is defined as the minimum amount of thermodynamic work (i.e. energy) required to remove an electron from a solid to a point in the vacuum immediately outside the solid surface [38], smaller work function values of $\mathrm{CNCl}_{x}$ indicates that electrons are easier to move to the surface under the influence of internal electric field [39], while excess $-\mathrm{Cl}$ groups increase the work function values of $\mathrm{CNCl}_{0.2}$. So, excess $-\mathrm{Cl}$ groups can result in the decrease of photocatalytic activity for $\mathrm{CNCl}_{0.2}$ sample.

The stability of optimized catalyst $\mathrm{CNCl}_{0.15}$ was also tested. It shows a stable HER rate after 5 cycling trips (Fig. 6(b)). Furthermore, the wavelength dependent apparent quantum yield (AQY) of $\mathrm{CNCl}_{0.15}$ reaches up to $13.6 \%$ at $420 \mathrm{~nm}$ (Fig. 6(c)).

The photocatalytic degradation of organic pollutants under visible light irradiation is shown in Figs. 6(d) and S8. After introducing $-\mathrm{Cl}$ groups, $\mathrm{CNCl}_{x}$ samples show superior activity to bulk $\mathrm{C}_{3} \mathrm{~N}_{4}$, demonstrating internal electric field can also improve the photocatalytic pollutant degradation performance. Among the $\mathrm{CNCl}_{x}$ samples, $\mathrm{CNCl}_{0.15}$ exhibits the highest activity, which is 5.8, 7.9 and 9.5 times of bulk $\mathrm{C}_{3} \mathrm{~N}_{4}$ for the degradation of RhB, MO and phenol, respectively (Fig. 6(d) and Table S1).

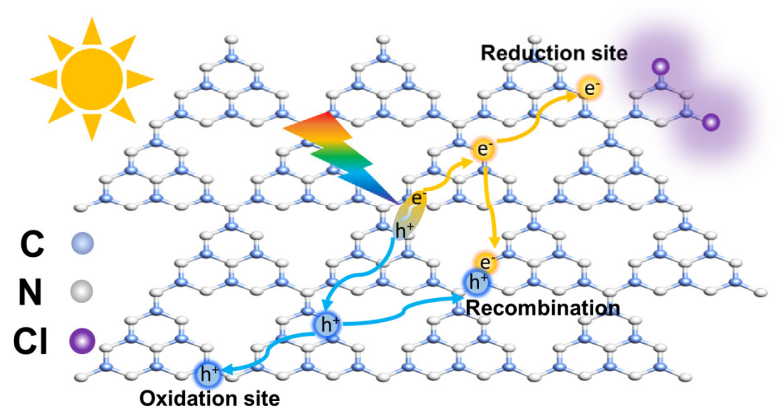

Fig. 7. Schematic illustration of proposed charge transfer in $\mathrm{CNCl}_{\mathrm{x}}$ under visible-light irradiation. 
Especially, $\mathrm{CNCl}_{0.15}$ can remove $97 \%$ of $\mathrm{RhB}$ within 60 minutes.

\section{Conclusions}

In this work, three important points that can influence the construction of intramolecular D-A system are explicated. To meet the requirements of ideal monomer, $\mathrm{C}_{4} \mathrm{H}_{3} \mathrm{Cl}_{2} \mathrm{~N}_{3}$ is chosen as the monomer to react with melamine to construct intramolecular D-A copolymers $\left(\mathrm{CNCl}_{x}\right)$. Introduction of $-\mathrm{Cl}$ group would change the distribution of the electron density over the heptazine rings, thus building an internal filed in the D-A system. The internal field can not only promote exciton dissociation into free electron and hole but also help free electrons and holes transfer to the surface of $\mathrm{CNCl}_{x}$, thus improving photocatalytic efficiency. The hydrogen evolution rate of $\mathrm{CNCl}_{0.15}$ is 15.3 times higher than that of bulk $\mathrm{C}_{3} \mathrm{~N}_{4}$ under visible light irradiation, with apparent quantum efficiency of $13.6 \%$ at 420 $\mathrm{nm}$. And it also presents 5.82, 7.93 and 9.53 times of bulk $\mathrm{C}_{3} \mathrm{~N}_{4}$ for the degradation of RhB, MO and phenol.

\section{Electronic supporting information}

Supporting information is available in the online version of this article.

\section{References}

[1] Y. Li, D. Zhang, J. Fan, Q. Xiang, Chin. J. Catal., 2021, 42, 627-636.

[2] Y. Li, D. Zhang, X. Feng, Q. Xiang, Chin. J. Catal., 2020, 41, 21-30.

[3] I. F. Teixeira, E. C. M. Barbosa, S. C. E. Tsang, P. H. C. Camargo, Chem. Soc. Rev., 2018, 47, 7783-7817.

[4] H. Wang, X. Zhang, Y. Xie, Mater. Today, 2019, 23, 72-86.

[5] L. Lin, Z. Lin, J. Zhang, X. Cai, W. Lin, Z. Yu, X. Wang, Nat. Catal., 2020, 3, 649-655.

[6] G. Zhang, G. Li, Z.-A. Lan, L. Lin, A. Savateev, T. Heil, S. Zafeiratos, X. Wang, M. Antonietti, Angew. Chem. Int. Ed., 2017, 56, 13445-13449.

[7] C. T. Poon, D. Wu, V. W. Yam, Angew. Chem. Int. Ed., 2016, 55, 3647-3651.
[8] X. Fan, L. Zhang, R. Cheng, M. Wang, M. Li, Y. Zhou, J. Shi, ACS Catal., 2015, 5, 5008-5015.

[9] J. Zhang, G. Zhang, X. Chen, S. Lin, L. Mçhlmann, G. D. G. Lipner, M. Antonietti, S. Blechert, X. Wang, Angew. Chem. Int. Ed., 2012, 51, 3183-3187.

[10] G. Zhang, X. Wang, J. Catal., 2013, 307, 246-253.

[11] S. Zhao, X. Zhao, H. Zhang, J. Li, Y. Zhu, Nano Energy, 2017, 35, 405-414.

[12] J. Li, D. Wu, J. Iocozzia, H. Du, X. Liu, Y. Yuan, W. Zhou, Z. Li, Z. Xue, Z. Lin, Angew. Chem. Int. Ed., 2019, 58, 1985-1989.

[13] J. Zhang, X. Chen, K. Takanabe, K. Maeda, K. Domen, J. D. Epping, X. Fu, M. Antonietti, X. Wang, Angew. Chem. Int. Ed., 2010, 49, 441-444.

[14] H. Kim, S. Gim, T. H. Jeon, H. Kim, W. Choi, ACS Appl. Mater. Interfaces, 2017, 9, 40360-40368.

[15] Y. Yu, W. Yan, W. Gao, P. Li, X. Wang, S. Wu, W. Song, K. Ding, J. Mater. Chem. A, 2017, 5, 17199-17203.

[16] K. Li, M. Sun, W.-D. Zhang, Carbon, 2018, 134, 134-144.

[17] C. Ye, X.-Z. Wang, J.-X. Li, Z.-J. Li, X.-B. Li, L.-P. Zhang, B. Chen, C.-H. Tung, L.-Z. Wu, ACS Catal., 2016, 6, 8336-8341.

[18] M. Marple, J. Badger, I. Hung, Z. Gan, K. Kovnir, S. Sen, Angew. Chem. Int. Ed., 2017, 56, 9777-9781.

[19] G. Liu, G. Zhao, W. Zhou, Y. Liu, H. Pang, H. Zhang, D. Hao, X. Meng, P. Li, T. Kako, J. Ye, Adv. Funct. Mater., 2016, 26, 6822-6829.

[20] H. Ou, X. Chen, L. Lin, Y. Fang, X. Wang, Angew. Chem. Int. Ed., 2018, 57, 8729-8733.

[21] F. Li, M. Han, Y. Jin, L. Zhang, T. Li, Y. Gao, C. Hu, Appl. Catal. B, 2019, 256, 117705.

[22] X. Wang, K. Maeda, A. Thomas, K. Takanabe, G. Xin, J. M. Carlsson, K. Domen, M. Antonietti, Nat. Mater., 2009, 8, 76-80.

[23] X. Mamtimin, R. Matsidik, I. Nurulla, Polymer, 2010, 51, 437-446.

[24] J. Sehnert, K. Baerwinkel, J. Senker, J. Phys. Chem. B, 2007, 111, 10671-10680.

[25] Y. Hu, Y. Shim, J. Oh, S. Park, S. Park, Y. Ishii, Chem. Mater., 2017, 29, 5080-5089.

[26] Z.-F. Huang, J. Song, L. Pan, Z. Wang, X. Zhang, J.-J. Zou, W. Mi, X. Zhang, L. Wang, Nano Energy, 2015, 12, 646-656.

[27] R. Gao, L. Pan, H. Wang, X. Zhang, L. Wang, J.-J. Zou, ACS Catal., 2018, 8, 8420-8429.

[28] R. Gao, L. Pan, H. Wang, Y. Yao, X. Zhang, L. Wang, J.-J. Zou, Adv. Sci., 2019, 6, 1900054.

\section{Graphical Abstract}

Chin. J. Catal., 2021, 42: 1168-1175 doi: 10.1016/S1872-2067(20)63733-0

\section{Donor-acceptor carbon nitride with electron-withdrawing chlorine} group to promote exciton dissociation

Jing-Wen Zhang, Lun Pan, Xiangwen Zhang, Chengxiang Shi*, Ji-Jun Zou* Tianjin University; Collaborative Innovative Center of Chemical Science and Engineering (Tianjin)

Compared with bulk $\mathrm{C}_{3} \mathrm{~N}_{4}$, donor-acceptor carbon nitride catalysts exhibit much higher photocatalytic performance by incorporating electron-withdrawing $-\mathrm{Cl}$ group as terminal group, which can build internal electric field to promote the exciton dissociation and charge carrier transfer.

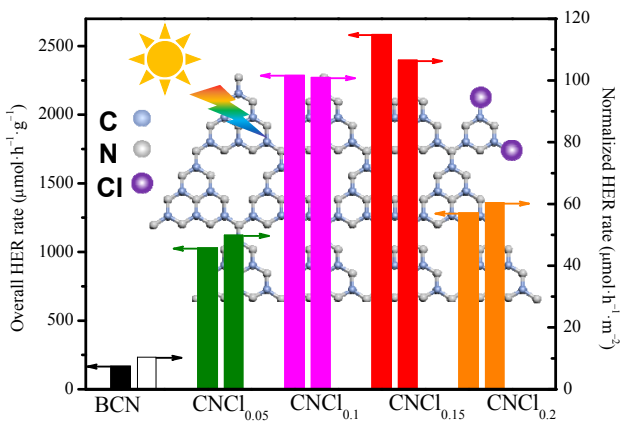


[29] Q. Yang, S. Hu, Y. Yao, X. Lin, H. Du, Y. Yuan, Chin. J. Catal., 2021, 42, 217-224.

[30] L. Hao, L. Kang, H. Huang, L. Ye, K. Han, S. Yang, H. Yu, M. Batmunkh, Y. Zhang, T. Ma, Adv. Mater., 2019, 31, 1900546.

[31] P. Pasman, F. Rob, J. W. Verhoeven, J. Am. Chem. Soc., 1982, 104, 5127-5133.

[32] Z. Sun, Y. Jiang, L. Zeng, L. Huang, ChemSusChem, 2019, 12, 1325-1333.

[33] H. Yu, J. Li, Y. Zhang, S. Yang, K. Han, F. Dong, T. Ma, H. Huang, Angew. Chem. Int. Ed., 2019, 58, 3880-3884.

[34] Q. Han, Z. Cheng, B. Wang, H. Zhang, L. Qu, ACS Nano, 2018, 12, 5221-5227.
[35] F. Chen, Z. Ma, L. Ye, T. Ma, T. Zhang, Y. Zhang, H. Huang, Adv. Mater., 2020, 32, 1908350.

[36] H. Wang, S. Jiang, S. Chen, X. Zhang, W. Shao, X. Sun, Z. Zhao, Q. Zhang, Y. Luo, Y. Xie, Chem. Sci., 2017, 8, 4087-4092.

[37] F. Liu, R. Shi, Z. Wang, Y. Weng, C. M. Che, Y. Chen, Angew. Chem. Int. Ed., 2019, 58, 11791-11795.

[38] A. Kahn, Mater. Horizons, 2016, 3, 7-10.

[39] Y. Zhou, C. Fuentes-Hernandez, J. Shim, J. Meyer, A. J. Giordano, H. Li, P. Winget, T. Papadopoulos, H. Cheun, J. Kim, M. Fenoll, A. Dindar, W. Haske, E. Najafabadi, T. M. Khan, H. Sojoudi, S. Barlow, S. Graham, J.-L. Brédas, S. R. Marder, A. Kahn, B. Kippelen, Science, 2012, 336, 327.

\title{
带有吸电子-Cl基团的供体-受体氮化碳的构建及其光催化性能
}

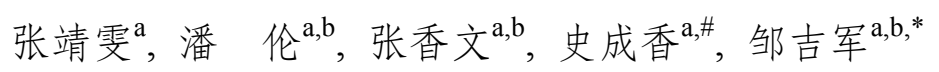 \\ ${ }^{a}$ 天津大学化学工程与技术学院, 绿色合成与转化教育部重点实验室, 天津 300072 \\ ${ }^{\mathrm{b}}$ 天津化学化工协同创新中心, 天津 300072
}

\begin{abstract}
摘要: 聚合物氮化碳 $\left(\mathrm{C}_{3} \mathrm{~N}_{4}\right)$ 因具有可见光响应特性、良好的化学稳定性、无毒性等优点而成为一类极具吸引力的光催化剂. 遗憾的是, 由于本征库仑相互作用, $\mathrm{C}_{3} \mathrm{~N}_{4}$ 中的光生电子和空穴通常以激子的形式存在, 导致迁移到表面的光生电子和空穴 数量减少, 从而降低了光催化活性, 因此人们做了大量的研究工作来促进激子解离成自由电子和空穴. D-A体系可以诱导 内部电场的产生, 从而促进激子解离成自由电子和空穴, 因此, 构建供体-受体(D-A)体系是一种有效地促进激子解离的方 法. 然后在内电场作用下, 自由电子和空穴也能够更加容易地转移到共聚物表面, 从而发生相应的光催化还原和氧化反应.

本文选择了2-氨基-4,6-二氯嘧啶 $\left(\mathrm{C}_{4} \mathrm{H}_{3} \mathrm{Cl}_{2} \mathrm{~N}_{3}\right)$ 作为单体, 与三聚氰胺共聚形成分子内共聚物 $\left(\mathrm{CNCl}_{x}\right)$ 来构建 D-A 体系. 由 于分子结构相似, $\mathrm{C}_{4} \mathrm{H}_{3} \mathrm{Cl}_{2} \mathrm{~N}_{3}$ 与 $\mathrm{C}_{3} \mathrm{~N}_{3}\left(\mathrm{NH}_{2}\right)_{3}$ 分子具有良好的化学相容性. 在共聚过程中, $\mathrm{C}_{4} \mathrm{H}_{3} \mathrm{Cl}_{2} \mathrm{~N}_{3}$ 在 $219 \sim 222{ }^{\circ} \mathrm{C}$ 升华, 三聚 氧胺在 $300{ }^{\circ} \mathrm{C}$ 升华, 在温度继续升高到 $550{ }^{\circ} \mathrm{C}$ 的过程中, 气相混合物充分混合并发生共聚反应. 在共聚过程中, 如果 $\mathrm{C}_{4} \mathrm{H}_{3} \mathrm{Cl}_{2} \mathrm{~N}_{3}$ 分子与 $\mathrm{C}_{3} \mathrm{~N}_{3}\left(\mathrm{NH}_{2}\right)_{3}$ 反应, 那么三聚氧胺沿着这个方向的聚合将终止, 因此吸电子- $\mathrm{Cl}$ 基团将全部位于共聚分子的 末端.

相较于体相 $\mathrm{C}_{3} \mathrm{~N}_{4}, \mathrm{CNCl}_{x}$ 样品活性均有所提高, 且随着- $\mathrm{Cl}$ 基团数量的增加, $\mathrm{CNCl}_{x}$ 样品活性先提高后降低, 其中 $\mathrm{CNCl}_{0.15}$ 样品活性最高. $\mathrm{CNCl}_{0.15}$ 在可见光下的析氢速率是体相 $\mathrm{C}_{3} \mathrm{~N}_{4}$ 的 15.3 倍, 在 $420 \mathrm{~nm}$ 处的表观量子效率为 $13.6 \%$. 对 $\mathrm{RhB}, \mathrm{MO}$ 和 苯酚的降解速率分别为体相 $\mathrm{C}_{3} \mathrm{~N}_{4}$ 的 5.82, 7.93和9.53倍. 构建分子内 D- $\mathrm{A}$ 体系以后, $\mathrm{C}_{3} \mathrm{~N}_{4}$ 活性提高主要是因为随着末端- $\mathrm{Cl}$ 基 团的增加, 材料的吸光能力和激子解离效率提高. 而且- $\mathrm{Cl}$ 基团也可以充当电子的俘获位点, 浓度进一步升高会降低电荷转 移的效率使活性降低. $\mathrm{EIS}$ 的奈奎斯特图和 $i-t$ 曲线结果表明, $\mathrm{CNCl}_{0.15}$ 的电弧半径最小, 光电流最大, 说明其具有最低的电阻 和最高的载流子传输效率. 紫外光电子能谱测试结果表明, $\mathrm{CNCl}_{x}$ 功函数值较小, 电子更容易在内部电场的作用下移动到 表面, 而过量的 $-\mathrm{Cl}$ 基团增加了 $\mathrm{CNCl}_{0.2}$ 的功函数值, 导致 $\mathrm{CNCl}_{0.2}$ 样品的光催化活性降低.
\end{abstract}

关键词: 氮化碳; 供体-受体; 内电场; 激子; 产氢

收稿日期: 2020-09-18. 接受日期: 2020-11-03. 上网时间: 2021-03-05.

*通讯联系人. 电话/传真: (022)27892340; 电子信箱: jj_zou@tju.edu.cn

\#通讯联系人. 电话/传真: (022)27892340; 电子信箱: cxshi@tju.edu.cn

基金来源：国家自然科学基金(21676193, 21978200, 51661145026).

本文的电子版全文由Elsevier出版社在ScienceDirect上出版(http://www.sciencedirect.com/journal/chinese-journal-of-catalysis). 